\title{
THE INFLUENCE OF LENGTH OF RELATIONSHIP, GENDER AND AGE ON THE RELATIONSHIP INTENTION OF SHORT-TERM INSURANCE CLIENTS: AN EXPLORATORY STUDY
}

\author{
TFJ Steyn \\ School of Business, Cameron University, USA \\ PG Mostert and JNW de Jager \\ School of Business Management, North-West University, Potchefstroom Campus
}

\begin{abstract}
Building long-term relationships with clients is extremely beneficial for organisations. This does not necessarily imply, however, that the clients themselves need or want a long-term relationship with an organisation. Relationship marketing could profitably be looked at from the client's perspective, at the same time identifying those clients who have a strong relationship intention and would, in fact, like to engage in a long-term relationship with organisations.

The objective of this research was to explore whether three aspects relating to clients, that is, the varying lengths of their relationship with organisations, their age and their gender display significantly different levels of relationship intention. Relationship intention is measured in terms of constructs like involvement, expectations, forgiveness, feedback and fear of relationship loss.

Non-probability sampling was used in this study, and 114 respondents from the short-term insurance industry completed self-administered questionnaires. Findings indicate that, for a group of high relationship-intention clients of a short-term insurance organisation, no practically significant discrimination exists on any of the relationship-intention constructs for clients' length of relationship, gender or age.
\end{abstract}

JEL L14, 84

1

\section{Introduction}

Relationship marketing can be seen as an orientation that seeks to develop close interaction with selected customers, suppliers and competitors for value creation through cooperative and collaborative efforts (Hollenson, 2003: 10). Kotler and Armstrong (2001: 9) put forward the same notion, suggesting that relationship marketing is a process of creating, maintaining and enhancing strong, valueladen relationships with clients and other stakeholders.

Relationship marketing is therefore focused not only on client relations, but also on expanding profitable relationships with suppliers, partners and even competitors to establish a successful, mutually-beneficial relationship in terms of value or profit. Building long-term relationships with clients also means a number of benefits for organisations through repeat sales and referrals, which lead in turn to increased sales, market share and profits. According to Disney (1999: 491) clients also benefit from long-term organisation-client relationships by gaining familiarity, personal recognition, discounts, credit advances, or even friendship. However, this does not necessarily imply that clients need or want to establish a long-term relationship with an organisation.

A highly relationship-oriented organisation would not be able to develop a long-term relationship with a client who did not wish to reciprocate. There is thus a definite need to look at relationship marketing from the clients' 
perspective and to identify those who would like to support long-term relationships with organisations (Donaldson \& O’Toole, 2002: 8).

\section{2}

\section{Literature background}

\subsection{Relationship marketing}

In a relationship-based marketing environment, an organisation has to look beyond single transactions. Those within the organisation should acknowledge that every client represents a potential stream of revenue and long-term earnings (Barnes, 2000: 19).

The nature of services forces the buyer or client into intimate contact with the seller, thereby facilitating the development of social bonds (O’Mally \& Tynan, 2003: 35). Hansen, Sandvik and Selnes (2002: 494) likewise hold that service encounters must be viewed, first and foremost, as social encounters. Grönroos (2000: 6-7) found that, if several of these encounters follow each other in a continuous or discrete fashion, a relationship may emerge.

Implementing a relationship marketing strategy brings a number of benefits for organisations (Lamb, Hair, McDaniel, Boshoff \& Terblanche, 2004: 11; O'Mally \& Prothero, 2004: 1287; Bowen \& Shoemaker, 2003: 31; Christopher, Payne \& Ballantyne, 2002: 8; Lovelock \& Wirtz, 2001: 352; Barnes, 2000: 19; Doyle, 2000: 81; Grönroos, 2000: 131 and White \& Schneider, 2000: 241). These include lower business costs, an increase in client spending, referrals and price-premiums. All these benefits, however, can be attributed to an increase in client retention. An example evident in the short-term insurance industry is that a five percentage point increase in client retention rate can yield an 84 percent increase in profits per client (Peck, Payne, Christopher \& Clark, 1999: 47).

The implementation of a relationship marketing strategy benefits both the organisation and the client. According to Barnes (2000: 126) clients experience three sets of benefits associated with the establishment of long-term organisation-client relationships: confidence, social and special treatment benefits.
Research carried out by Chiou (2004: 687) indicates that clients commit to a relationship with an organisation only as long as the transaction provides superior value. Various theoretical discussions support the crucial importance of providing value on a sustained basis for the successful development of long-term client relationships (Ferrel \& Hartline, 2005: 121; Lamb et al., 2004: 10; Bowen \& Shoemaker, 2003: 36; Christopher et al., 2002: 21 and Barnes, 2000: 13).

Service providers are in an excellent position to establish profitable, long-term relationships with their clients. This is especially true of financial services like short-term insurance (Sharma \& Patterson, 2000: 473). There is evidence that the South African short-term insurance industry realises the vital importance of building a continuous relationship with consumers. The South African Insurance Association (SAIA) acknowledges consumers as an important component of their stakeholder relationship management framework (SAIA, 2007a: 24)

As many clients lack the requisite technical knowledge and skills to confidently predict the outcome of their financial services investment and buying decisions, they have to trust their financial advisor (Sharma \& Patterson, 2000: 473). This means that trust is a necessary precursor for the establishment of long-term client relationships, especially in a South African short-term insurance environment characterised by high levels of crime and high incidence levels of motor vehicle accidents (SAIA, 2007a: 13-14). The concept of trust, its requirements, benefits and importance in the short-term insurance industry thus merits discussion.

\subsubsection{Trust}

A real change from traditional marketing thinking and behaviour takes place when an organisation makes the strategic decision to adopt a relationship rather than a transactional focus. This means that certain areas in business that might previously have been ignored require more attention with the implementation of a relationship marketing approach. According to Pride \& Ferrel (2006: 367) the development of trust between the organisation and its clients warrants special attention 
Trust is arguably the single most important relationship-marketing tool available to an organisation (Chiou, 2004: 688; Sirdeshmukh, Singh \& Sabol, 2002: 15 and Grönroos, 2000: 31). This is because signalling trust to clients is a vital first step for organisations in gaining co-operative behaviour and is therefore fundamental to establishing a long-term relationship (Fletcher \& Peters, 1997: 526). From the marketing perspective, this suggests that the development of trust should be a fundamental component in any marketing strategy intended to lead to the creation of genuine client relationships (Barnes, 2000: 121).

\subsubsection{Defining trust}

According to Hocutt (1998: 192) some authors define trust as a willingness to rely on an exchange partner in whom one has confidence. This relates to the definition by Sharma \& Patterson (2000: 473) who define trust as "a feeling or belief on the part of a buyer that a seller will fulfil the promises made during an exchange transaction". Morgan and Hunt captured the essence of trust when they argued that trust is essentially one party's assurance of another party's reliability and integrity (as cited by Hart, Smith, Sparks \& Tzokas, 1999: 543).

Hocutt (1998: 192) found that authors sometimes define trust as the belief that a partner's word or promise is reliable and that the partner would act in a way that would have positive outcomes and would not take unexpected actions resulting in negative outcomes. This, in turn, corresponds with the definition by Barnes (2000: 120) who defines trust as "a willingness to act in a certain manner because of confidence that the partner will provide the expected gratifications and a generalised expectance held by an individual that the word, promise or statement of another individual can be relied on".

\subsubsection{Requirements for the establishment of trust in client relationships}

The above definitions demonstrate that competence and reliability play a significant role in the establishment of trust. According to Coulter and Coulter (2002: 37) competence can be defined as the degree to which clients perceive that the organisation possesses the required skills and knowledge to supply the service needed. Bloemer, De Ruyter \& Wetzels (1999: 1084) define reliability as the ability to deliver the promised service dependably and accurately. Sirdeshmukh et al. (2002: 17) found that the expectation of reliable service and competent performance from an organisation has been noted as a precursor to the development of client trust.

A series of repeated transactions is, in itself, another important prerequisite for the establishment of trust. According to Fletcher and Peters (1997: 527) client reliance on trust will emerge only when transactions with the organisation have already been successfully completed. This is because trust evolves out of past experience and prior actions (Barnes, 2000: 120).

The idea that trust emerges from prior contact is based on the premise that clients learn more about the organisation and develop trust based on the organisation's competence and the reliability of its service through ongoing interaction (Coulter \& Coulter, 2002: 37). Trust can therefore be developed only through tangible, operational demonstrations of the organisation's competence and fulfilment of promises, supported by qualitative relationship development (Fletcher \& Peters, 1997: 537).

However, a series of transactions does not, on its own, constitute a close relationship. As transactions are successfully repeated and trust is established between the organisation and client, each party has to sacrifice its independence in order to demonstrate their commitment to the relationship (Adcock, 2000: 258). The result is a dependability that takes place when a relationship progresses to the point where emphasis shifts away from specific behaviour towards an evaluation of the qualities of the organisation and its employees (Barnes, 2000: 121). In other words, trust is placed in the organisation itself and not in the specific actions of the organisation.

\subsubsection{The benefits of building trust in the organisation}

The major benefit for organisations in building client trust is the establishment of strong client relationships. However, apart from this, there are additional benefits. 
According to Fletcher and Peters (1997: 527), trust influences the clients' willingness to demonstrate tolerance. In other words, clients who trust the organisation more will be more forgiving about service failures. This corresponds with the findings of Ball, Coelho and Machas (2003: 1275), who state that "clients who are not willing to trust an organisation in a competitive marketplace are less likely to be loyal". More trusting clients, therefore, appear to be more loyal to a particular organisation and less prone to switching to competitors.

The existence of trust in a relationship can also act as an insurance proxy for clients against risks and unexpected behaviour in the future (Grönroos, 2000: 38). This is because trust tends to reduce the risk associated with opportunistic behaviour by the organisation. In other words, the client's trust in the organisation's intentions will not perceive the possibility of the organisation's seeking only its own interests, hiding relevant information or violating agreements (Guitierrez, Cillian \& Izquierdo, 2004: 355). This, combined with clients' trust in an organisation's competence, will reduce their insecurity when buying and encourage them to undertake transactions involving higher degrees of risk (Guitierrez et al., 2004: 355).

\subsubsection{Building trust in the short-term insu- rance industry}

It is obvious that trust is particularly important when actions have to be undertaken without being able to monitor the actions of the other party in advance (Fletcher \& Peters, 1997: 527). In an organisation-client context, this can be explained with an example from the short-term insurance industry where clients pay a monthly premium, trusting the insurance organisation to pay out a claim should the client suffer some unforeseeable future damages.

Consider the insurance organisation confronted with a claim from a family who have recently lost their home in a fire. The organisation could prolong the process as well as the family's grief by harassing the family with questions on how the fire started or who was at fault. Although these questions are important, the insurance organisation should first ensure that the client's emotional needs are met. By dealing with the claim quickly and efficiently, the insurance organisation both sends the message that it trusts the client and shows that the organisation is committed to its relationship with the client (Barnes, 2000: 146).

It is also interesting to note that the South African short-term insurance industry realises the importance of fostering consumer trust. A consumer education initiative was launched in 2005 by SAIA to channel the 0.2 percent after-tax profits to be spent by SAIA members on financial literacy consumer education into projects that would build consumer trust through financial literacy education (SAIA, 2007b; SAIA, 2006).

Another important element required for the establishment of long-term organisation-client relationships is the development of relationship commitment. The concept of commitment will therefore be explored, as follows.

\subsubsection{Commitment}

According to Bowen and Shoemaker (2003: 34), relationship marketers generally believe that the future of buyer-seller relationships depends on the partners' commitment to the relationship. One can therefore presume, like White and Schneider (2000: 240), that the success of an organisation's relationship marketing efforts can be measured by the degree of commitment displayed by clients towards the organisation. It thus becomes evident that commitment is increasingly regarded as a central construct in relationship marketing.

\subsubsection{Defining commitment}

Relationship commitment is defined in its simplest terms as a willingness or desire to maintain a relationship (Fullerton, 2005: 100; Grönroos, 2000: 38 and Hocutt, 1998: 195). Bauer, Grether and Leach (2002: 156) define commitment in terms of the desire on the part of the involved parties to develop a relationship, as well as their willingness to make short-term sacrifices to maintain it. However, Bowen and Shoemaker (2003: 34) provide a more comprehensive definition, defining commitment as a client's "belief that an ongoing relationship is so important that he or she is willing to 
work at maintaining the relationship and are (sic) willing to make short-term sacrifices to realise long-term benefits". This definition of commitment is more in line with the relationship marketing perspective because of its emphasis on a long-term approach to relationship benefits. It also paves the way for Grönroos's (2001: 38) explanation that commitment is a motivational mechanism for entering into a business transaction with another party.

\subsubsection{The benefits of client commitment}

The above definition of commitment also highlights one of the benefits for organisations in establishing client commitment. As the definition states, clients in a committed relationship are willing to make short-term sacrifices. This means that they would not, according to Sharma and Patterson (2000: 473), actively seek out alternative service providers or organisations in order to gain short-term benefits like price reductions.

This is because commitment encourages clients to resist attractive short-term alternatives offered by other organisations in favour of the expected benefits of supporting long-term relationships with existing service providers. Hence, the level of commitment determines relationship strength and clients' intention to remain in a relationship with an organisation (Hocutt, 1998: 189). This, in turn, increases profitability, as client commitment can help organisations retain their clients and drive them to repeat buying (Guitierrez et al., 2004: 355). However, committing to a relationship possibly involves a lesser sacrifice for an organisation that wants to secure business with existing clients, than that of clients, who could be asked to give up the freedom to choose between and negotiate with alternative suppliers (Adcock, 2000: 375). It thus becomes evident that, in order to retain clients on the basis of their commitment, the organisation must provide service quality that offers value to the client.

\subsection{Service quality}

Nickels and Wood (1997: 323) found that without a high standard of service quality the organisation would ultimately damage and lose its relationships with clients. This has particularly ominous implications for South African organisations, as South Africa was recently placed $44^{\text {th }}$ out of 46 countries in terms of service quality standards (Lamb et al., 2004: 19). In the light of establishing long-term relationships, the improvement of service quality warrants special attention.

\subsubsection{Defining service quality}

Most definitions conceptualise service quality as the result of a comparison between client expectations and actual service performance (Pride \& Ferrel, 2006: 374; Bloemer et al., 1999: 1084 and Kandampully, 1998: 433). A similar definition is given by Meek, Meek, Palmer and Parkinson (2005: 163), who define service quality as the match between expectations of service quality and client perceptions of the service. However, two words in this last definition that need to be highlighted are "client perceptions". According to Nickels and Wood (1997: 323), quality is not determined by the organisation but by the client. The client's perception of the actual service performance would determine the quality of that particular service. Organisations should therefore establish how clients perceive service quality.

\subsubsection{Clients' criteria for evaluating service quality}

The greatest obstacle for clients in evaluating service quality is the intangible nature of services. It is inherently difficult for clients to evaluate something they cannot hear, feel, taste, smell or see (Pride \& Ferrel, 2006: 374). The question is: What criteria do clients use to evaluate service quality? Grönroos (2000: 81) identified four such criteria as:

- Professionalism and skills: Do the organisation's employees have the requisite knowledge and skills to solve the client's problems in a professional manner?

- Attitudes and behaviour: Are employees concerned about the organisation's clients and are they interested in solving clients' problems in a friendly, spontaneous way?

- Accessibility and flexibility: Is the organisation managed and operated so that clients have easy access to the service? Is 
the organisation also prepared to adjust to clients' demands and wishes in a flexible way?

- Reliability and trustworthiness: Do clients believe they can rely on the organisation to keep promises and perform with their best interests at heart?

\subsubsection{The advantages of improving service quality}

Apart from aiding the establishment of longterm client relationships, an improvement in service quality also raises client-satisfaction levels. Client satisfaction, in turn, improves relationship strength, which leads to relationship longevity and client relationship profitability. It is thus evident that client satisfaction plays a key role in client retention. Fully-satisfied clients are more likely to become loyal clients, or even advocates for the organisation and its services (Ferrel \& Hartline, 2005: 125). Improved client loyalty reduces the costs of acquiring new clients while making existing clients less price sensitive and less likely to explore alternative suppliers, all of which contribute to higher profits (Ferrel \& Hartline, 2005: 125 and Meek et al., 2005: 217). It is interesting to note that the benefits provided by the improvement of service quality correspond to a great degree with the overall benefits associated with relationship marketing.

\subsection{Relationship intention}

When clients prefer a relationship approach in which factors such as loyalty, trust and commitment are taken into account, they would be regarded as having a relationship intention. Kumar, Bohling and Ladda (2003: $667,669)$ define relationship intention as a client's intention to build a relationship with an organisation while buying a product or using a service attributed to the organisation. Clients like this possess a high affinity with, are emotionally attached to, and possess a great amount of trust in the organisation.

According to Kumar et al. (2003: 670) a consumer's relationship intention is measured by using five constructs. They are the client's involvement with the service, his/her expectations of the service, the willingness to forgive service failures, whether the client provides feedback to the organisation and whether the person would fear the loss of a relationship with the organisation's employees or with the organisation itself.

\subsubsection{Involvement}

Kumar et al. (2003: 670) define a client's involvement in services as "the degree to which a person would willingly intend to engage in a relationship activity without any coercion or obligation". Clients participate in the service production and delivery process at varying levels of motivation (Kalamas, Laroche \& Cezard, 2002: 294). According to Varki and Wong (2003: 90) this involvement influences the clients' interests in relationships with service providers, as well as their expectations of relational activities initiated by the service provider. Clients who are more involved with an organisation express greater intrinsic willingness to maintain their relationship with the organisation (Varki \& Wong, 2003: 87). Some of the characteristics of highly-involved clients (such as their propensity to build long-term relationships as well as to form more realistic expectations) can be seen as advantageous.

\subsubsection{Expectations}

According to Coye (2004: 55) expectations reflect an individual's subjective probabilities about the current or future existence of a particular state of affairs. Kumar et al. (2003: 670) state that clients automatically develop expectations when they buy a product or service. However, a client with high expectations of an organisation will have a greater intention to build a relationship with that particular organisation, because s/he will be more concerned about the quality of the product or service (Kumar et al., 2003: 670). The antecedents of client expectations are:

- Clients'perception of service quality: Kalamas et al. (2002: 295) argue that clients who perceive past service performance as satisfactory will have positive future expectations of the organisation;

- Clients' image of the organisation: Clients' evaluations of service quality are filtered 
through their image of a service provider. Ojasalo (2001: 208) however, points out that clients' image of an organisation can sometimes lead to unrealistic expectations about what the organisation is actually capable of in terms of service delivery, creating a situation in which these expectations cannot possibly be fulfilled;

- Word-of-mouth communication among clients: Owing to the degree of similarity between recipient and communicator, the lack of financial motive on the part of the communicator and the experiential nature of services, word-of-mouth communications are perceived to be more trustworthy than organisationally-sponsored information sources (Kalamas et al., 2002: 295). When it comes to services like insurance, wordof-mouth communications are therefore a very important source for client information (Clow \& Kurtz, 1997: 232);

- Tangible cues linked to the organisation: Tangible cues are also among the most important dimensions that clients use to evaluate an organisation's capabilities and service quality (Boshoff \& Staude, 2003: 11). Tangibles like the exterior of the company facility, interior décor, furniture and equipment, as well as the employees' dress, affect both what clients expect during the next service encounter and their image of the organisation (Kalamas et al., 2002: 295);

- Service promises made by the organisation: According to Clow and Kurtz (1997: 232) explicit service promises are personal and non-personal statements made by a service provider that influence client expectations and purchase intentions. Kalamas et al. (2002: 295) maintain that service promises are among the most important criteria in the formation of client expectations and that they are positively related to a client's desired and predicted level of service expectations.

\subsubsection{Forgiveness}

In the context of interpersonal relationships, Enright, Freedman and Rique (1998: 46-47) define forgiveness as people's willingness to abandon their resentment, negative judgment and indifferent behaviour to others who unjustly hurt them. Forgiveness in the organisationclient relationship context could be seen as loyal clients' willingness to overlook a negative service outcome and thus their willingness to "forgive" what they perceive as a service failure (Robbins \& Miller, 2004: 97). This makes it clear that the concept of service failures should also be examined in order to fully understand the concept of client forgiveness.

\subsubsection{Feedback}

Clients who provide feedback on their service encounters with an organisation are in a better position to receive service recovery from an organisation. Having benefited from service recovery, these clients will then be more loyal to the organisation and will also trust the organisation more (Weun, Beatty \& Jones, 2004: 133). According to Kumar et al. (2003: 670), clients who are inclined to give feedback, whether positive or negative, to the organisation, also tend to have a higher relationship intention.

\subsubsection{Fear of relationship loss}

Fear of relationship loss is a switching cost or barrier which deters clients from switching to a competitor's product or service (Aydin, Ozer \& Arazil, 2005: 91; Caruana, 2002: 256). A barrier can be any factor that makes it more difficult or expensive for clients to change from a current brand or service provider to another (Beerli, Josefa \& Quintana, 2004: 258 and Jones, Mothersbaugh, Beatty \& Sharon, 2000: 261).

Caruana (2002: 258) views relational switching costs as the "psychological or emotional discomfort due to the loss of identity and breaking of bonds which consist of personal relationship loss and brand relationship costs". Clients with high involvement fear losing their relationship with an organisation and subsequently show a high intention towards relationship building (Kumar et al., 2003: 670) because they are emotionally attached to an organisation. They will be reluctant to switch because they fear the loss of emotional attachment, with either the brand or the employees with whom the client is in contact. 
3

\section{Problem statement and objectives}

Even if an organisation is highly relationship oriented, it will not be able to develop a longterm relationship with a client if that client does not wish to engage in such a relationship. While a great deal of research has been carried out on relationship marketing from the organisational perspective, there remains a need to view the relationship marketing construct from the client's viewpoint. It is hypothesised that different categories of clients will exhibit different relationship intentions.

The objectives of the study are to:

- Investigate the relationship intention of short-term insurance clients in terms of involvement, expectations, forgiveness, feedback and fear of relationship loss;

- Determine the influence of the length of the organisation-client relationship regarding relationship intention;

- Identify whether there are differences between certain demographic variables, such as gender and age, and clients' relationship intention.

\section{4}

\section{Method}

\subsection{Sample}

The short-term insurance industry specialises in the delivery of short-term insurance products, such as household and car insurance (Bitter, 2004: 29). This study focuses on the relationship intention of short-term insurance clients. The client base of a leading short-term insurance organisation in South Africa was used for the research.

In this study, non-probability sampling was used with reliance on available subjects. Three hundred and sixty (360) questionnaires were distributed to 18 branches (20 each) of the short-term insurance organisation to be completed by clients of each separate branch situated in different geographical locations in South Africa.

\subsection{Measuring instrument}

The study used self-administered questionnaires. The decision to use this type of measuring instrument was based on its cost-effectiveness (Cooper \& Schindler, 2003: 341 and Struwig \& Stead, 2001: 86, 88). Self-administered questionnaires are also perceived to be more impersonal, guaranteeing the respondent greater anonymity (Cooper \& Schindler, 2003: 341 ) and thus encouraging them to disclose personal information, feelings and attitudes more readily.

\subsection{Questionnaire}

The questionnaire measured relationship intention according to a respondent's involvement, expectations, forgiveness, feedback and fear of relationship loss. The questionnaire was adapted from one developed by Kumar et al. (2003: 675). Likert scales were used and measured responses on the continuum of "no, definitely not; no; neutral; yes; and yes, definitely".

\subsection{Data analysis}

The study population was surveyed by means of a convenience sample. Effect sizes according to Cohen's d-values indicating practically significant effects were used to determine differences between the means of different groups. Effect sizes (d-values) were calculated by using the following formula (Cohen, 1988: 20-27):

$d=\frac{\left|\bar{x}_{1}-\bar{x}_{2}\right|}{s_{\max }}$

where:

- $d=$ effect size;

- $\bar{x}_{1}-\bar{x}_{2}$ is the difference between means of two compared groups; and

- $s_{\max }$ is the maximum standard deviation of the two groups being compared.

Effect sizes were interpreted as follows (Ellis \& Steyn, 2003: 51-53 and Cohen, 1988: 20-27):

- $\mathrm{d} \approx 0.2$ indicating a small effect with no practical significance;

- $\mathrm{d} \approx 0.5$ indicating a moderate effect; and 
- $\mathrm{d} \approx 0.8$ or larger indicating a practically significant effect.

For the following reasons effect sizes rather than tests for statistical significance were used (Steyn \& Ellis, 2006: 172-175 and Steyn, 2005: 3-4):

- Non-standardised questionnaires were used. Such questionnaires do not clearly indicate the difference in means between groups. Effect sizes can, in such circumstances, help to judge the practical significance of differences in means between groups;

- The realised sample of respondents was small and the line of inquiry represents new research in the context of relationship intention. In such a setting, effect sizes identify important differences between groups; and

- The sample was a non-probability sample. When dealing with non-probability samples, it is inappropriate to calculate statistical significance. Effect sizes offer a much better alternative for judging significance.
Cohen (1988: 25) found that "the terms 'small', 'medium' and 'large' are relative, not only to each other, but also to the area of behavioral science or even more particularly to the specific content and research method employed in any given investigation". Cohen (1988: 25) also found that effect sizes are likely to be small in new areas of research enquiry. This is owing to the fact that the phenomena under study are usually not under sufficient experimental or measurement control.

\section{5}

Results

One hundred and fourteen (114) usable questionnaires were returned from 10 branches of the short-term insurance organisation nationwide. Table 1 shows the results of the reliability tests.

Table 1

Reliability tests

\begin{tabular}{|l|c|}
\hline \multicolumn{1}{|c|}{ Relationship intention construct } & Cronbach's alpha coefficient \\
\hline Involvement & 0.531 \\
\hline Expectations & 0.443 \\
\hline Forgiveness & 0.775 \\
\hline Feedback & 0.525 \\
\hline Fear of relationship loss & 0.897 \\
\hline
\end{tabular}

From Table 1 it can be seen that in three cases the Cronbach's alpha values were lower than the accepted cut-off point of 0.7 (Bland \& Altman, 1997: 572). This might be attributable to the exploratory nature of the study and the fact that only three items per construct were used. Field (2005: 668) however, states that low Cronbach's alpha values can be expected in most social science studies and values of smaller than 0.7 might be acceptable owing to the diversity of constructs being measured if the study deals with psychological constructs like attitudes and opinions (as is the case in this study).

\subsection{Length of organisation-client relationships}

Figure 1 depicts the period which the client has been with the organisation. 


\section{Figure 1}

Length of organisation-client relationship

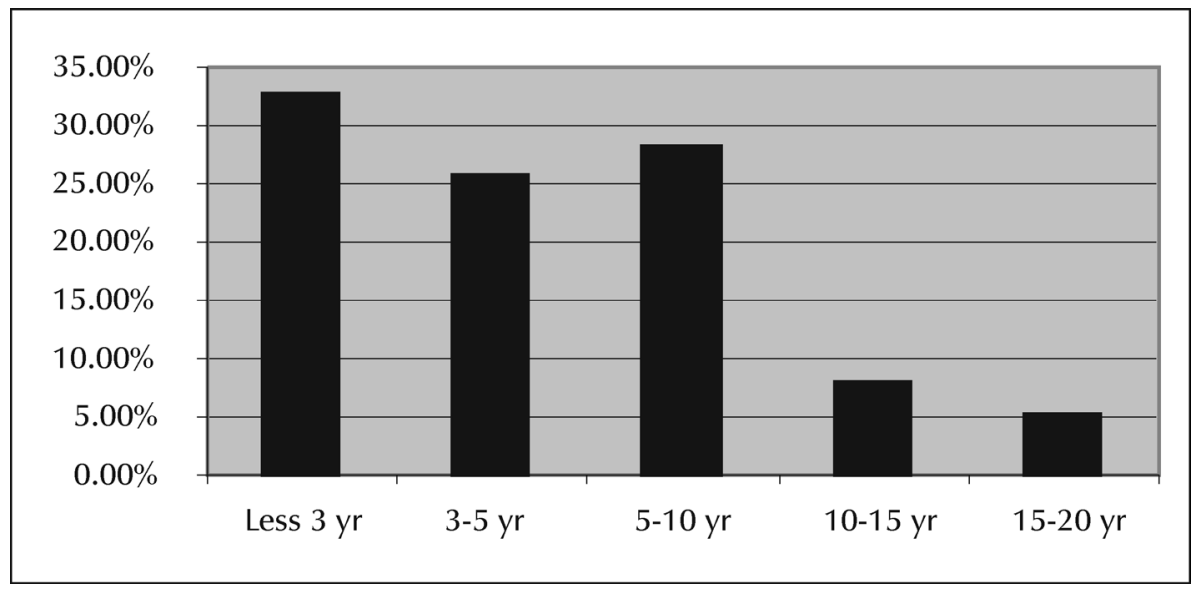

Figure 1 shows that the majority of clients (58 per cent) had been with the organisation for five years and less, while 13 per cent had been with the organisation for more than 10 years. For analytical purposes it was decided to treat the $>10-15$ and $>15-20$ years categories as one.
The relationship intention scores for these groups are shown in Table 2. A group's relationship intention values consist of that group's scores when measured in terms of the relationship intention constructs of involvement, expectations, forgiveness, feedback and fear of relationship loss.

Table 2

Relationship intention scores of length of client relationships

\begin{tabular}{|c|c|c|c|c|c|c|c|}
\hline \multirow{2}{*}{$\begin{array}{l}\text { Relationship } \\
\text { intention } \\
\text { construct }\end{array}$} & \multirow{2}{*}{$\begin{array}{l}\text { Relationship } \\
\text { length }\end{array}$} & \multirow{2}{*}{$\begin{array}{c}\text { Mean } \\
(\%)\end{array}$} & \multirow[t]{2}{*}{ Std dev } & \multicolumn{4}{|c|}{ d-value } \\
\hline & & & & $\begin{array}{l}\text { Less } 3 \\
\text { years }\end{array}$ & $\begin{array}{c}3-5 \\
\text { years }\end{array}$ & $\begin{array}{l}>5-10 \\
\text { years }\end{array}$ & $\begin{array}{c}>10-20 \\
\text { years }\end{array}$ \\
\hline \multirow[t]{4}{*}{ Involvement } & $<3$ years & 69.2 & 12.9 & - & 0.34 & 0.44 & 0.44 \\
\hline & 3-5 years & 74.3 & 15.0 & 0.34 & - & 0.04 & 0.09 \\
\hline & $>5-10$ years & 74.8 & 10.7 & 0.44 & 0.04 & - & 0.06 \\
\hline & $>10-20 y e a r s$ & 75.7 & 14.7 & 0.44 & 0.09 & 0.06 & - \\
\hline \multirow[t]{4}{*}{ Expectations } & $<3$ years & 57.5 & 18.3 & - & 0.12 & 0.02 & 0.14 \\
\hline & 3-5 years & 59.7 & 16.6 & 0.12 & - & 0.14 & 0.25 \\
\hline & $>5-10$ years & 57.2 & 18.0 & 0.02 & 0.14 & - & 0.13 \\
\hline & $>10$-20years & 54.7 & 19.6 & 0.14 & 0.25 & 0.13 & - \\
\hline
\end{tabular}




\begin{tabular}{|c|c|c|c|c|c|c|c|}
\hline \multirow[t]{4}{*}{ Forgiveness } & $<3$ years & 56.1 & 18.4 & - & 0.25 & 0.28 & 0.04 \\
\hline & 3-5 years & 61.8 & 22.7 & 0.25 & - & 0.03 & 0.20 \\
\hline & $>5-10$ years & 61.3 & 16.6 & 0.28 & 0.03 & - & 0.18 \\
\hline & $>10-20$ years & 57.1 & 23.5 & 0.04 & 0.20 & 0.18 & - \\
\hline \multirow[t]{4}{*}{ Feedback } & $<3$ years & 87.0 & 12.2 & - & 0.01 & 0.16 & 0.19 \\
\hline & $3-5$ years & 86.9 & 12.8 & 0.01 & - & 0.17 & 0.17 \\
\hline & $>5-10$ years & 89.1 & 12.8 & 0.16 & 0.17 & - & 0.34 \\
\hline & $>10-20$ years & 84.7 & 11.9 & 0.19 & 0.17 & 0.34 & - \\
\hline \multirow{4}{*}{$\begin{array}{l}\text { Fear of } \\
\text { relationship } \\
\text { loss }\end{array}$} & $<3$ years & 61.1 & 22.8 & - & 0.01 & 0.08 & 0.10 \\
\hline & $3-5$ years & 61.4 & 21.3 & 0.01 & - & 0.07 & 0.11 \\
\hline & $>5-10$ years & 63.1 & 23.5 & 0.08 & 0.07 & - & 0.18 \\
\hline & $>10-20$ years & 58.7 & 25.5 & 0.10 & 0.11 & 0.18 & - \\
\hline \multirow[t]{4}{*}{ Total } & $<3$ years & 66.6 & 10.1 & - & 0.25 & 0.34 & 0.09 \\
\hline & $3-5$ years & 69.4 & 11.3 & 0.25 & - & 0.05 & 0.13 \\
\hline & $>5-10$ years & 70.0 & 7.8 & 0.34 & 0.05 & - & 0.18 \\
\hline & $>10-20$ years & 67.7 & 12.7 & 0.09 & 0.13 & 0.18 & - \\
\hline
\end{tabular}

Table 2 it shows that nearly all the d-values display insignificant effect sizes. However, medium-sized d-values for involvement were found when comparing those clients with a relationship length of fewer than three years with those with a relationship length of more than five years and up to 10 years $(\mathrm{d}=0.44)$, as well as those with a relationship length of $>$ 10 years and up to 20 years $(\mathrm{d}=0.44$ and the highest involvement score of 75.7 per cent). The lowest involvement score (69.2 per cent) was for the group with a relationship length of fewer than three years.

No significant d-values were identified when comparing clients with different relationship lengths in terms of their expectations. The highest expectations score (59.7 per cent) was for those with a relationship length of between three and five years, while the lowest expectations score (54.7 per cent) was for clients with a relationship length of $>10$ years and up to 20 years.
As illustrated in Table 2, clients with a relationship length of fewer than three years showed no significant difference $(d=0.04)$ when compared to clients with a relationship of $>10$ years and up to 20 years in terms of their forgiveness. However, d-values of 0.25 and 0.28 were found when comparing those with the shortest relationship length (fewer than three years) with those with a relationship length of three years up to five years. The highest forgiveness score $($ mean $=61.8$ per cent $)$ was for those with a relationship length of three years up to five years, while the lowest forgiveness score (56.1 per cent) was for clients with a relationship length of fewer than three years.

From Table 2 it can be observed that there were no significant differences in effect sizes when comparing clients with different relationship lengths in terms of feedback. The highest feedback score $($ mean $=89.1$ per cent) was for those with a relationship of more than five years 
up to ten years, while the lowest feedback score (84.7 per cent) was for clients with a relationship length of more than 10 years up to 20 years.

As illustrated in Table 2, there were also no significant differences in effect sizes when comparing clients with different relationship lengths in terms of fear of relationship loss. The highest fear of relationship loss score (63.1 per cent) was for those with a relationship of more than five years up to ten years, while the lowest fear of relationship loss score (58.7 per cent) was for those with a relationship length of more than ten years up to 20 years.

\subsection{Gender}

Almost two thirds (66 per cent) of the total respondents were male and 34 per cent were female. Compared to the population gender ratio of approximately 52 per cent female and 48 per cent male in South Africa, this is not representative. Table 3 gives a comparison between the relationship scores of men and women.

Table 3

Relationship intention scores in terms of gender

\begin{tabular}{|l|c|c|c|c|c|}
\hline \multirow{2}{*}{\begin{tabular}{c}
\multirow{2}{*}{$\begin{array}{c}\text { Relationship intention } \\
\text { construct }\end{array}$} \\
\cline { 2 - 6 }
\end{tabular}} & \multicolumn{2}{c|}{ Male } & \multicolumn{2}{c|}{ Female } & \multirow{2}{*}{ d-value } \\
\hline Involvement & 73.5 & 12.8 & 71.1 & 14.2 & 0.17 \\
\hline Expectations & 55.6 & 17.2 & 61.1 & 17.4 & 0.32 \\
\hline Forgiveness & 59.2 & 19.9 & 57.1 & 18.9 & 0.11 \\
\hline Feedback & 87.00 & 12.7 & 87.3 & 12.2 & 0.02 \\
\hline Fear of relationship loss & 61.3 & 22.1 & 60.5 & 23.9 & 0.03 \\
\hline Total relationship intention score & 68.3 & 9.7 & 67.8 & 10.4 & 0.05 \\
\hline
\end{tabular}

As indicated in Table 3, all the d-values were practically insignificant. Expectations, however, showed a relatively higher d-value of 0.32 . The expectations scores are 55.6 per cent for men and 61.1 per cent for women.

The highest mean for men and women was for feedback ( 87 per cent), and the lowest mean for men was for expectations (55.6 per cent). The lowest mean for women was for forgiveness at 57.1 per cent.
As no practically significant differences were detected between the respective genders, it seems that relationship intention does not discriminate between these customer groups on any of the relationship intention constructs.

\subsection{Age}

Respondents' age distribution is reflected in Table 4, with an indication of the relationship intention scores in the different age groups.

Table 4

Relationship intention scores for different age groups

\begin{tabular}{|l|l|c|c|c|c|c|}
\hline \multirow{2}{*}{$\begin{array}{c}\text { Relationship } \\
\text { intention construct }\end{array}$} & \multicolumn{1}{|}{ Age group } & Mean (\%) & Std dev & \multicolumn{3}{c|}{ d-value } \\
\cline { 5 - 8 } & & & & $\begin{array}{c}\mathbf{2 0 - 3 5} \\
\text { years }\end{array}$ & $\begin{array}{c}36-50 \\
\text { years }\end{array}$ & $\begin{array}{c}\text { Older } \\
\text { than 50 }\end{array}$ \\
\hline \multirow{2}{*}{ Involvement } & $20-35$ years & 69.4 & 13.5 & - & 0.22 & 0.24 \\
\cline { 2 - 8 } & $36-50$ years & 72.3 & 11.8 & 0.22 & - & 0.05 \\
\cline { 2 - 8 } & Older than 50 & 73.0 & 15.0 & 0.24 & 0.05 & - \\
\hline
\end{tabular}




\begin{tabular}{|c|c|c|c|c|c|c|}
\hline \multirow[t]{3}{*}{ Expectations } & $20-35$ years & 58.0 & 17.3 & - & 0.32 & 0.07 \\
\hline & $36-50$ years & 63.0 & 14.4 & 0.32 & - & 0.36 \\
\hline & Older than 50 & 56.2 & 18.9 & 0.07 & 0.36 & - \\
\hline \multirow[t]{3}{*}{ Forgiveness } & 20-35 years & 60.00 & 19.1 & - & 0.28 & 0.22 \\
\hline & $36-50$ years & 65.3 & 16.1 & 0.28 & - & 0.48 \\
\hline & Older than 50 & 55.6 & 20.2 & 0.22 & 0.48 & - \\
\hline \multirow[t]{3}{*}{ Feedback } & 20-35 years & 90.0 & 10.3 & - & 0.54 & 0.20 \\
\hline & $36-50$ years & 84.2 & 10.7 & 0.54 & - & 0.24 \\
\hline & Older than 50 & 87.4 & 13.4 & 0.20 & 0.24 & - \\
\hline \multirow{3}{*}{$\begin{array}{l}\text { Fear of relationship } \\
\text { loss }\end{array}$} & 20-35 years & 54.2 & 22.4 & - & 0.33 & 0.35 \\
\hline & $36-50$ years & 61.5 & 19.3 & 0.33 & - & 0.04 \\
\hline & Older than 50 & 62.5 & 23.8 & 0.35 & 0.04 & - \\
\hline \multirow[t]{3}{*}{ Total } & $\begin{array}{l}20-35 \text { years } \\
(14 \% \text { of total })\end{array}$ & 66.6 & 8.7 & - & 0.36 & 0.08 \\
\hline & $\begin{array}{l}36-50 \text { years } \\
(23 \% \text { of total })\end{array}$ & 69.7 & 8.5 & 0.36 & - & 0.18 \\
\hline & $\begin{array}{l}\text { Older than } 50 \\
(63 \% \text { of total })\end{array}$ & 67.6 & 11.5 & 0.08 & 0.18 & - \\
\hline
\end{tabular}

As shown in Table 4, the majority of the sample (63 per cent) is 50 years and older, while 23 per cent of respondents are between the ages of 36 and 50 years, and 14 per cent of respondents are between the ages of 20 and 35 years.

Table 4 indicates that few significant effect sizes were found when comparing different age groups in terms of their involvement. However, those aged between 20 and 35 years showed relatively higher d-values when compared to those aged between 36 and 50 years $(d=0.22)$, and those older than 50 years $(\mathrm{d}=0.24)$. This contrasts sharply with the d-value of 0.05 for the comparison between those aged 36 to 50 years to those older than 50 years. The highest involvement score ( 73 per cent) was for those respondents aged older than 50 years, while the lowest involvement score (69.4 per cent) was for clients between 20 years and 35 years.
Although the d-values for expectations were insignificant, those aged between 36 and 50 years showed higher d-values when compared to the group aged between 20 years and 35 years $(d=0.32)$ and those aged older than 50 years $(d=0.36)$. This is in contrast with the low $d-$ value of 0.07 for the comparison between those respondents between 20 years to 35 years of age and those older than 50 years. The highest expectations score (63.1 per cent) was for the age group 36 to 50 years, while the lowest expectations score (56.2 per cent) was for the over 50 age group.

A moderate practically significant effect size $(d=0.48)$ was found when comparing those respondents aged between 36 and 50 years and the age group 50 years and older in terms of the forgiveness construct. The forgiveness scores of the above-mentioned age groups are 65.3 per 
cent and 55.6 per cent respectively. All the other $\mathrm{d}$-values were practically insignificant.

A medium-sized d-value of 0.54 was found between the 20 to 35 year age group and those between 36 and 50 years in terms of feedback. The average feedback scores of the abovementioned age groups are 90 per cent (20 to 35 age group), and 84.2 per cent for those aged between 36 and 50 years. The other d-values were all insignificant.

Although the effect sizes for fear of relationship loss were not practically significant, the age group 20 to 35 years showed relatively higher d-values when compared to those respondents between 36 and 50 years $(\mathrm{d}=0.33)$ and those older than 50 years $(\mathrm{d}=0.35)$. This differs considerably with the insignificant effect size (d $=0.04$ ) for the comparison between those aged 36 to 50 years and those older than 50 years. The highest fear of relationship loss score (62.5 per cent) was for the older than 50 years age group while the lowest fear of relationship loss score (54.2 per cent) was for those clients between 20 and 35 years.

\section{6}

\section{Conclusions and recommendations}

\subsection{Length of relationship}

The majority of the respondents who participated in this survey (58 per cent) have been with the organisation for fewer than five years. Those clients with the "shortest" relationship with the organisation (fewer than three years) have the lowest involvement score. Higher involvement scores were found for those clients who have a relationship with the organisation for longer than three years. The involvement scores for these clients also remain relatively consistent as the length of the client-organisation relationship progresses.

Clients who have had a relationship with the organisation for fewer than three years are less forgiving than those who have been with the organisation for between three and 10 years. When the relationship exceeds 10 years, forgiveness decreases.

It appears that clients cross an "involvement barrier" when their relationship with the surveyed short-term insurance organisation progresses beyond three years. The establishment of trust is therefore important when initiating relationships with new clients. However, it is also important to realise that a client usually possesses a high degree of perceived risk when acquiring a financial service. In establishing trust with new clients, the organisation must strive to lower the perceived risk that clients associate with the purchase of insurance services. Clients should therefore know that the service outcome will be satisfactory and the organisation could do this by initially explaining to new clients how it manages its service process. This can, for example, be done by explaining beforehand how, in the case of a claim, the organisation manages and executes the claims process.

The organisation must also communicate the reliability of its service delivery as well as the competence of its employees in offering superior service, because these are seen as a precursor to the development of client trust (Sirdeshmukh $e t$ al., 2002: 17). However, the organisation has to live up to these expectations by demonstrating its reliability and competence. A client's first claim is therefore extremely important, as it is a test of the organisation's ability to live up to its promises. The organisation's employees should be highly supportive to a client when (s)he submits a first claim and should deal with it in an efficient and professional manner.

Every service encounter should be seen as a social encounter and an opportunity for the organisation's employees to become familiar with the client. In order to induce clients to become more involved in their relationship with the organisation, it is important to increase personal interaction between the organisation's clients and its employees. The organisation must adapt its communication and interaction with clients as they cross the involvement barrier and become more involved in their relationship with the organisation.

However, this said, it is important to note that no practically significant differences were detected between different lengths of relationship for clients of the short-term insurance organisation for any of the relationship intention constructs. It therefore follows that, for purposes of this study, where respondents all 
showed a relatively high relationship intention (i.e. between 66.6 per cent and 70.0 per cent for client groups with different lengths of relationship), relationship intention does not discriminate between these customer groups on any of the relationship intention constructs.

\subsection{Gender}

There seems to be no difference between men and women with regard to their relationship intention, except in the area of expectations. Women tend to form higher expectations of their service providers. The organisation could utilise women's higher expectations levels in the implementation of a relationship marketing strategy when targeting them for insurance products.

Organisations should therefore broaden their female clients' word-of-mouth capabilities by persuading them to share their positive experience with other women. They should also develop communication materials, such as information sheets and brochures, for female clients to make available to non-clients. Furthermore, organisations could also target opinion leaders such as respected businesswomen or other influential women within the community to endorse their services.

However, it is important to note that no practically significant differences were detected on the basis of clients' gender for any of the relationship intention constructs. It therefore follows that, for purposes of this study (where both male and female respondents showed a relatively high relationship intention [i.e. 68.3 per cent for males and 67.8 per cent for females]), relationship intention does not discriminate between these customer groups on any of the relationship intention constructs.

\subsection{Age}

It would appear that the youngest age group (i.e. those between the ages of 20 and 35) had the lowest involvement score and also the lowest fear of relationship loss score. Clients in this age group are therefore not as emotionally connected to the organisation's service or its employees. Developing relationship marketing strategies for these clients should therefore be done with caution.
However, the age group between 20 and 35 years of age displayed higher feedback scores when compared to those clients between the ages of 36 and 50 years. Clients between the ages of 36 and 50 scored the highest in terms of expectations and forgiveness, while the youngest age group (20 -35 years) and the older than 50 years age group had lower expectations and forgiveness scores.

Clients who would respond more favorably to relationship-marketing strategies are those aged between 36 and 50 years. These clients showed the highest scores in both expectations and forgiveness. These clients hold high expectations of the organisation, but will also be more forgiving should their expectations not be met. Larson (1995) found that middle-aged households with children spend the most on insurance compared with other households. It would be sensible to target these clients with relationship-marketing strategies.

Data showed that forgiveness among clients older than 50 years decreases. It is postulated that many of the clients within this age group have retired, which has reduced their income and increased their price sensitivity. These clients could still represent a profitable market segment for the organisation. However, pricing strategies should form part of the relationshipmarketing strategies used for them.

However, it is also important to note that no practically significant differences were detected between different age groups of clients of the short-term insurance organisation for any of the relationship-intention constructs. It therefore follows that, for purposes of this study, where clients in all age groups showed a relatively high relationship intention (i.e. between 66.6 per cent and 67.6 per cent for the different age groups) relationship intention does not discriminate between these customer groups on any of the relationship-intention constructs.

It was hypothesised that different categories of clients would exhibit different relationship intentions. From the results of this exploratory study it can, however, be deduced that no such practically significant differences exist. None were detected for clients of the short-term insurance organisation for any of the relationship intention constructs on length of relationship with the organisation, gender or age of respondents. 
7

\section{Limitations and future research}

The reason behind the relatively low d-values could be explained by the fact that the study and measurement of relationship intention is an entirely new area of research enquiry. According to Cohen (1988: 25), small-effect sizes are likely in new areas of research enquiry, as the phenomena under study are usually not under good experimental or measurement control. The final sample size (114) was relatively small and was biased in favour of the male population (66 per cent).

Future research should aim to rectify this limitation and must measure the relationship intention of clients in other industries and other sectors within the insurance industry (e.g. life insurance). Future studies should also include clients with low relationship-intention scores to ascertain whether differences exist for the respective relationship intention constructs for different categories of clients based on low relationship intention. Should it be found that relationship intention does not discriminate between different categories of low relationship intention clients either, relationship intention can be considered as a possible alternative basis for market segmentation.

\section{8}

\section{References}

1 ADCOCK, D. (2000) Marketing Strategies for Competitive Advantage, John Wiley: Chichester, pp 405.

2 AYDIN, S.; OZER, G. \& ARASIL, O. (2005) "Client loyalty and the effect of switching costs as a moderator variable: A case in the Turkish mobile phone market”, Marketing Intelligence \& Planning, 23(1): 89-103.

3 BALL, D.; COELHO, P.S. \& MACHAS, A. (2003) "The role of communication and trust in explaining client loyalty", European Journal of Marketing, 38(9/10): 1272-1293.

4 BARNES, J.G. (2000) Secrets of Client Relationship Management: It's All about how You Make Them Feel, McGraw-Hill: New York.

5 BAUER, H.H.; GRETHER, M. \& LEACH, M. (2002) "Building customer relations over the Internet", Industrial Marketing Management, 31: 155-163.
6 BEERLI, A.; JOSEFA, D.M. \& QUINTANA, A. (2004) "A model of client loyalty in the retail banking market", European Journal of Marketing, 38(1/2): 253-275.

7 BITTER, N. (2004) "The state of the South African short-term insurance market", Cover, 13(12): 28-32.

8 BLAND, J.M. \& ALTMAN, D.G. (1997) "Statistics notes: Cronbach's Alpha", Accessed November 17, 2006 http://bmj.com/cgi/elettersubmit/314/7080/572

9 BLOEMER, J.; DE RUYTER, K. \& WETZELS, M. (1999) "Linking perceived service quality and service loyalty: A multi-dimensional perspective", European Journal of Marketing, 33(11/12): 10821106.

10 BOSHOFF, C. \& STAUDE, G. (2003)

"Satisfaction with service recovery: Its measurement and its outcomes", South African Journal of Business Management, 34(3): 9-16.

11 BOWEN, J.T. \& SHOEMAKER. S. (2003) "Loyalty: A strategic commitment", Cornell Hotel \& Restaurant Administration Quarterly, 44(5/6): 3146.

12 CARUANA, A. (2002) "Service loyalty: The effects of service quality and the mediating role of client satisfaction", European Journal of Marketing, 36(7/8): 811-829.

13 CHIOU, J. (2004) “The antecedents of clients' loyalty toward internet service providers", Information \& Management, 41(6): 685-695.

14 CHRISTOPHER, M.; PAYNE, A. \& BALLANTYNE, D. (2002) Relationship Marketing: Creating Stakeholder Value, ButterworthHeineman: Oxford.

15 CLOW, K.E. \& KURTZ, D.L. (1997) “The antecedents of client expectations of services: An empirical study across four industries", Journal of Services Marketing, 11(4/5): 230-248.

16 COHEN, J. (1988) Statistical Power Analysis for the Behavioural Sciences, Erlbaum: Hillsdale, NJ.

17 COOPER, D.R. \& SCHINDLER, P.S. (2003) Business Research Methods, McGraw-Hill: New York.

18 COULTER, K.S. \& COULTER, R.A. (2002) "Determinants of trust in a service provider: The moderating role of length of relationship", Journal of Services Marketing, 16(1): 35-50.

19 COYE, R.W. (2004) "Managing client expectations in the service encounter, International Journal of Service Industry Management. 15(1): 54-71.

20 DISNEY, J. (1999) Client satisfaction and loyalty: The critical elements of service quality", Total Quality Management, 10(4/5): 491-497. 
21 DONALDSON, B. \& O`TOOLE, T. (2002) Strategic Market Relationships: From Strategy to Implementation, John Wiley: West Sussex.

22 DOYLE, P. (2000) Value-Based Marketing: Marketing Strategies for Corporate Growth and Shareholder Value, John Wiley: Chichester.

23 ELLIS, S.M. \& STEYN, H.S. (2003) "Practical significance (effect sizes) versus or in combination with statistical significance (p-values)",

Management Dynamics, 12(4): 51-53.

24 ENRIGHT, R.D.; FREEDMAN, S., \& RIQUE, J. (1998) "The psychology of interpersonal forgiveness", in Enright, R.D. \& North, J. (eds.) Exploring Forgiveness, University of Wisconsin Press: Madison, pp 46-62.

25 FERREL, O.C. \& HARTLINE, M.D. (2005) Marketing Strategy, Thomson South-Western: Ohio.

26 FIELD, A. (2005) Discovering Statistics Using SPSS, Sage: London.

27 FLETCHER, K.P. \& PETERS, L.D. (1997) “Trust and direct marketing environments: A client perspective", Journal of Marketing Management, 13(6): 523-539.

28 FULLERTON, G. (2005) "The service qualityloyalty relationship in retail services: Does commitment matter?" Journal of Retailing and Client Services, 12(2): 99-111.

29 GRÖNROOS, C. (2000) Service Management and Marketing: A Client Relationship Management Approach, John Wiley: Chichester.

30 GRÖNROOS, C. (2001) Service Management and Marketing: a Customer Relationship Management Approach, Antony Rowe: Great Britain.

31 GUITIERREZ, S.S.M.; CILLIAN, J.G. \& IZQUIERDO, C.C. (2004) "The client's relational commitment: Main dimensions and antecedents", Journal of Retailing and Client Services, 11(2004): 351-367.

32 HANSEN, H.; SANDVIK, K. \& SELNES, F. (2002) "When clients develop commitment to the service employee: Exploring the direct and indirect effects on propensity to stay", Advances in Client Research, 29(1): 494.

33 HART, S.; SMITH, A.; SPARKS, L. \& TZOKAS, N. (1999) "Are loyalty schemes a manifestation of relationship marketing?" Journal of Marketing Management, 15: 541-562.

34 HOCUTT, M.A. (1998) "Relationship dissolution model: Antecedents of relationship commitment and the likelihood of dissolving a relationship", International Journal of Service Industry Management, 9(2): 189-200.

35 HOLLENSON, S. (2003) Marketing Management: A Relationship Approach, Pearson Education: Harlow.
36 JONES, M.A.; MOTHERSBAUGH, D.L.; BEATTY, S.E. \& SHARON, E. (2000) "Switching barriers and repurchase intentions in services", Journal of Retailing, 76(2): 259-274.

37 KALAMAS, M.; LAROCHE, M. \& CEZARD, A. (2002) "A model of the antecedents of should and will service expectations", Journal of Retailing \& Client Services, 9(6): 291-308.

38 KANDAMPULLY, J. (1998) "Service quality to service loyalty: A relationship that goes beyond client services”, Total Quality Management, 9(6): 431-443.

39 KOTLER, P. \& ARMSTRONG, G. (2001) Principles of Marketing, Upper Saddle River, Prentice Hall: New Jersey.

40 KUMAR, V.; BOHLING, R. \& LADDA, R.N. (2003) "Antecedents and consequences of relationship intention: Implications for transaction and relationship marketing", Industrial Marketing Management, 32(8): 667-676.

41 LAMB, C.W.; HAIR, J.F.; MCDANIEL, C.; BOSHOFF, C. \& TERBLANCHE, N.S. (2004) Marketing, Oxford University Press: Cape Town.

42 LARSON, J. (1995) "Insurance at risk", American Demographics, 17(10): 52-57.

43 LOVELOCK, C. \& WIRTZ, J. (2001) Services Marketing: People, Technology, Strategy, PearsonPrentice Hall: New Jersey.

44 MEEK, H.; MEEK, R., PALMER, R. \& PARKINSON, L. (2005) Managing Marketing Performance, Elsevier Butterworth-Heineman: Oxford, 380p.

45 NICKELS, W.G. \& WOOD, M.B. (1997) Marketing: Relationships, Quality, Value, Worth: New York.

46 OJASALO, J. (2001) "Managing client expectations in professional services", Managing Service Quality, 11(3): 200-212.

47 O'MALLY, L. \& PROTHERO, A. (2004) "Beyond the frills of relationship marketing", Journal of Business Research, 57(11): 1286-1294.

48 O'MALLY, L. \& TYNAN, C. (2003) "Relationship marketing”, in Baker, M.J (ed.) The Marketing Book, Butterworth-Heineman: Oxford.

49 PECK, H.; PAYNE, A.; CHRISTOPHER, M. \& CLARK, M. (1999) Relationship Marketing: Strategy and Implementation, ButterworthHeineman: Oxford.

50 PRIDE, W.M. \& FERREL, O.C. (2006) Marketing: Concepts and Strategies, Houghton Mifflin: Boston.

51 ROBBINS, T.L. \& MILLER, J.L. (2004) "Considering client loyalty in developing service recovery strategies", Journal of Business Strategies, 21(2): 95-109. 
52 SAIA - See South African Insurance Association.

53 SHARMA, N. \& PATTERSON, P.G. (2000)

"Switching costs, alternative attractiveness and experience as moderators of relationship commitment in professional, client services", International Journal of Service Industry Management, 11(5): 470-490.

54 SIRDESHMUKH, D.; SINGH, J. \& SABOL, B. (2002) "Client trust, value, and loyalty in relational exchanges", Journal of Marketing, 66(1): 15-37.

55 SOUTH AFRICAN INSURANCE ASSOCIATION (2006) "SAIA FSC Consumer Education Initiative". http://www.saia.co.za/ member-section/57.html Accessed 12 February 2008.

56 SOUTH AFRICAN INSURANCE ASSOCIATION (2007a) 'SAIA annual review", http://www.saia.co.za/member-section/57.html Accessed 12 February 2008.

57 SOUTH AFRICAN INSURANCE ASSOCIATION (2007b) "SAIA Report: SAIA FSC consumer education initiative 2005". http:// www.saia.co.za/member-section/57.html Accessd 12 February 2008.

58 STEYN, H.S. (2005) Handleiding vir Bepaling van Effekgrootte-Indekse en Praktiese Betekenisvolheid.
(Manual for the determination of effect size indices and practical significance), Potchefstroom: Statistical Consultation Service, North-West University (Potchefstroom Campus).

59 STEYN, H.S. JR. \& ELLIS, S.M. (2006) "Die gebruik van effekgrootte-indekse by die bepaling van praktiese betekenisvolheid". (The use of effect size indices in the determination of practical significance), Suid-Afrikaanse Tydskrif vir Natuurwetenskap en Tegnologie, 25(3): 172-175.

60 STRUWIG, F.W. \& STEAD, G.B. (2001) Planning, Designing and Reporting Research, Pearson Education South-Africa: Cape Town.

61 VARKI, S. \& WONG, S. (2003) "Client involvement in relationship marketing of services", Journal of Service Research, 6(1): 83-91.

62 WEUN, S.; BEATTY, S.E. \& JONES, M.A. (2004) "The impact of service failure severity on service recovery evaluations and post-recovery relationships", Journal of Services Marketing, 18(2): 133-146.

63 WHITE, S.S. \& SCHNEIDER, B. (2000) "Climbing the commitment ladder: The role of expectations disconfirmation on clients' behavioral intentions", Journal of Service Research, 2(3): 240253. 